\title{
Human Remains in Rhodesian Ruins
}

\section{Author(s): Rich. N. Hall}

Source: The Geographical Journal, Vol. 34, No. 5 (Nov., 1909), pp. 577-578

Published by: geographicalj

Stable URL: http://www.jstor.org/stable/1777299

Accessed: 27-06-2016 04:02 UTC

\section{Your use of the JSTOR archive indicates your acceptance of the Terms \& Conditions of Use, available at}

http://about.jstor.org/terms

JSTOR is a not-for-profit service that helps scholars, researchers, and students discover, use, and build upon a wide range of content in a trusted digital archive. We use information technology and tools to increase productivity and facilitate new forms of scholarship. For more information about JSTOR, please contact support@jstor.org.

The Royal Geographical Society (with the Institute of British Geographers), Wiley are collaborating with JSTOR to digitize, preserve and extend access to The Geographical Journal 
time. The special maps of European countries are based on Waldseemüller's 'Carta Itineraria Europæ' of 1511, of the original issue of which no copy is now known. Dr. Wolkenhauer devotes especial attention to the map of the Rhine, which is important as probably possessing an originality not to be attributed to the rest. As regards the general character of the manuscript, he considers it to be best descrited as a "Kollegienbuch," i.e. a collection of notes and extracts made in connection with Münster's university studies, or possibly (in the case of some) with courses of instruction given by himself. Facsimiles of the more important of the maps accompany the paper.

\section{CORRESPONDENCE.}

\section{Human Remains in Rhodesian Ruins.}

Bulawayo, Rhodesia, September 11, 1909.

ON my return from a five months' tramp, with native porters, down the Sabi watershed in Mashonaland, I found, greatly to my surprise, the following paragraph circulated in several scientific papers. The paragraph (for all were identical) was as follows:-

"Dr. F. C. Shrubsall gives measurements and photographs of two crania and some long bones in the Natural History Department of the British Museum that are referred to by Mr. R. N. Hall in his work on Rhodesia, as having been found in the neighbourhood of the ruins. The contribution they offer to the controversy as to the antiquity of those ruins (which ruins not stated) is that, in Dr. Shrubsall's opinion, they are those of negroes of a similar type to those now found in Rhodesia."

Would you allow me to state that I have never referred to the crania and bones said to be in the British Museum, for the simple reason that until I read the paragraph I was unaware of their existence. Nor should I have done so had it been otherwise, for I should first have required to know in what ruins they were found, under what conditions, whether buried in the midden débris of subsequent squatters or other conditions of finding, and with what other articles they were associated, or who was the finder.

Very probably they are negroid remains, for after the abandonment of the older buildings by their original occupiers, the ruins in most instances have been converted into native cemeteries. This was the case in 1560 , when the Portuguese records state that the Beza ruins had been converted into a cemetery for "all the monomotapas (munu-mu-tapa = great receiver of tribute, or 'Great Robber') are buried there," and "they know how many kings they have had." The buildings were never intended for cemeteries, and burials take place in many of them to-day. This explains the natural reluctance of the natives to disclose the location of ruins, lest their burial-places should be disturbed. Numerous graves made in the debris of the very last series of subsequent squatters at Zimbabwe were discovered, and at many feet above the original floors, and also completely blocking up important passages. The heads in these graves, Mr. C. H. Read of the British Museum states, belonged to "the fourteenth century, or just possibly to the thirteenth century" (see 'Pre-Historic Rhodesia,' pp. 283-294), which is prior to Prof. MacIver's earliest date for the erection of the Temple!

I do not see how Dr. Shrubsall's statement as to the crania, etc., affects the controversy as to the origin of the culture of stone-building and rock-mining in

No. V.-November, 1909.]

$2 \mathrm{R}$ 
these territories. After perusing my 'Pre-Historic Rhodesia' every one must see that I am right in entering this protest.

The only possible explanation for Dr. Shrubsall's reference to myself may be found in Hall and Neal's 'Ancient Ruins of Rhodesia' (p. 107), as to the discovery at $M$ 'Telekwe ruins of native remains, with which was a piece of cloth with gold wire or thread woven in the pattern. Livio Sanuto, writing in 1581 of the country of the munu-mu-tapa, said, "The people wear cotton worked with gold thread." This is a definite statement made by Mr. Neal and myself as early as 1901, that the remains were negroid. This needed no explanation. Dr. Shrubsall's reference might have been to our note on p. 105, which related to a skull, and an arm and thigh-bone, found in the Chum ruins, West Gwanda, and taken to England by the Hon. Maurice Gifford, in 1896, and given by him to Prof. Thane, who later informed the authors that he had lost these remains, and could therefore give no opinion upon them. From the spot where they were found, and from their associated articles, the authors, who had never seen the remains, later declared them to be negroid of about the fifteenth or sixteenth century. In confirmation it may be said that cotton worked with gold thread was imported up to 1381, either from Persia or India, as the records state that the munu-mu-tapas decreed that their people should not wear cotton so worked and imported by foreigners, lest evil should come upon them. This historically recorded fact dates the articles and the remains with which they were buried. Moreover, long before 1581 some of the ruins were declared, by competent writers who had seen them, to be "foundations of ancient castles and palaces," and so "very ancient" that Dos Santos and others dated them to Solomonic times, while De Barros thought they belonged to Ptolemy's Agyzimba-a name of Bantu origin.

Rich. N. HaLl.

\section{Cloud Caps on Snowy Peaks.}

The following note, made during a ski-tour on the Jotunfjeld, Norway, last winter, suggests a possible explanation of the cloud phenomenon recorded and sketched by Mr. C. Reginald Enock in the October number of the Journal.

"February 21.-Magnificent calm sunny weather while crossing ice of Tyin lake (altitude 3500 feet). 10 A.M. Snow-peaks clear and sparkling against blue sky. A few small but distinct 'slurs' of cloud in the blue northwards. 11 A.M. The 'slurs' on the clear blue are very gradually and slowly coalescing into a level layer of well-marked stratus, which tends to sink towards the mountain-tops."

The phenomenon described by Mr. Enock has never been seen by the present writer. But in Norway light fogs may often be observed floating on still cold air (over a frozen tarn, for example), much as a layer of naphtha would float upon the surlace of water. Accordingly, one pictures such a cloud-formation as possible around any snowy summit which had chanced to catch the shade of some high fragmentary cloud in sunny windless weather. The summit would then powerfully chill the air in its vicinity, and be surrounded by a shell of cold air. The shading of a snow-summit in sunny weather by a distant cloud might be a chance circumstance, or one favoured by local climate and local topography. But when this happens, and a light fog settles upon the peak, the result would probably be a hollow canopy, which, as it thinned and melted, would be visible in section as a parasol-shaped cloud "obeyiug the form of the peak."

A. Oldham Lees. 